\title{
Diversification, Internal Capital Market, and Information Advantage
}

\author{
Chung-Hua Shih, Ching-Chih Wu*, Tung-Hsiao Yang \\ Department of Finance, National Chung Hsing University, Taichung City, Taiwan
}

Copyright $\bigcirc 2018$ by authors, all rights reserved. Authors agree that this article remains permanently open access under the terms of the Creative Commons Attribution License 4.0 International License

\begin{abstract}
We analyze the information advantage of insiders and institutional investors from the efficiency of internal capital market defined in Billett and Mauer [1]. The empirical evidence shows three major findings in this paper. First, the inefficient subsidies to constrained firms have significantly negative impact on the firm's long-term performance. In addition, the diversified firms with transfer segments, both efficient and inefficient transfer, have significantly positive effect on the firm's performance. Second, the insiders and institutional investors of diversified firms may use similar information regarding the internal capital market because they show the similar trading behavior with respect to efficient subsidies to both constrained and non-constrained segments. Finally, the insiders play a more important role in the firms' long-term performance. In sum, we conclude that both institutional investors and insiders have some information advantage of internal capital market. Insiders, however, have stronger impact on the diversified firms' long-term performance.
\end{abstract}

Keywords Diversification, Information Advantage, Internal Capital Market

\section{Introduction}

Diversification could create or destroy firm value. The existing evidence is mixed and support both argument. There is, however, a trade-off relationship in the firm's diversification. The major benefits, on the one hand, come from efficient internal capital allocation and/or debt-coinsurance effect [2-4]. On the other hand, the inefficient management of internal capital may also decrease the firm value [5-7]. There is extensive literature to show the supportive evidence in either the benefit or the cost or the trade-off relationship. Eventually, the diversification would affect the value of diversified firms. Even though the theoretical arguments and empirical results show that there is a discount for diversified firms, which implies the cost dominates the benefit in firm's diversification, some researchers find the positive effect of diversification on firm value.

The mixed results of the impact on firm value in diversification provide an opportunity to test the information advantage of institutional investors and insiders. Piotroski and Roulstone [8] find that insider and institutional trading accelerates the incorporation of the firm-specific component of future earnings news into prices alone. They also suggest that the influence of the firm's information environment depends on each party's relative information advantage. Due to the information asymmetry and the trade-off relationship between firm value and diversification, institutional investors and insiders may utilize similar information to adjust their holdings in the diversified firms, especially in the efficiency of allocation of internal capital. In contrast, they may view the diversification from different angles and behave differently after firm diversification.

For example, Baik, et al. [9] show that the level of and change in local institutional ownership predict future stock returns. They also find that positive relation between local institutional holdings and stock performance is pronounced in firms with high information asymmetry. In addition, the positive relation is stronger for holdings by institutions that are more likely to possess and exploit local information, such as local investment advisors, high local ownership institutions, and high local turnover institutions. Therefore, how institutional investors and insiders react to the firm diversification is the main issue in this project. Based on the trading data of both parties, we test the information advantage of institutional investors and insiders in firm diversification. The major contribution of this project is to link the informative effect in diversification with the information advantage of informed traders.

The trade-off relation between diversification and firm value mainly results from the efficiency of internal capital market. The efficiency of the allocation of internal capital depends on managerial ability and expertise. In addition, the firm specific characteristics in growth opportunities 
and financial constraints also play an important role in the trade-off relation. Informed traders, such as institutional investors or insiders, may have their information advantage regarding the private information in the internal capital market. How they utilize the information advantage in firm's diversification is important to all market participants. To the best of our knowledge, this project is the first paper to analyze the utilization of information advantage in diversification process.

Following [1], we classify the diversified firms into six groups based on their subsidies and transfers across segments in the internal capital market. They are efficient and inefficient subsidies to financially constrained segments, efficient and inefficient subsidies to unconstrained segments, and efficient and inefficient transfers. Each group has different results in the change of firm value with respect to the efficiency of the capital allocation. We observe the change of institutional holdings and insider trading in each group and test which party performs better in forecasting the change of firm value after diversification. The forecasting ability of firm's future performance is a key issue in recent corporate finance literature, which is relative to information advantage. For example, Wahal and McConnell [10] find no support for the contention that institutional investors cause corporate managers to behave myopically. Instead, they document a positive relation between industry-adjusted expenditures for expenditures for property, plant and equipment and research and development and the fraction of shares owned by institutional investors.

In addition to the forecasting ability, the institutional investors have another role in the diversification process, which is the influence in firm's corporate governance. Gillan and Starks [11] show that proposals sponsored by institutions or coordinated groups appear to act as substitutes gaining substantially more support than proposals sponsored by individuals. Therefore, institutional holdings may also play a role in the trade-off relation between diversification and firm value. That is institutional investors may substantially affect the efficiency of internal capital market and/or influence the agency problems in the diversification process. These issues do not get enough attention in the literature and we fit in this gap to provide empirical evidence about the role of institutional investors in the diversification.

The rest of the paper is organized as follows. We survey the related literature in Section II, which include the trade-off relation between diversification and firm value, the information advantage of institutional investors and insiders, and the corporate governance mechanism provided by institutional investors. In addition, we also summarize the research hypotheses of this paper. Section III describes the data collection and research design, which includes the definition of diversified firms and measures construction.

\section{Literature Review and Research Hypotheses}

\subsection{The Trade-off between Diversification and Firm Value}

The existing literature present mixed results in the trade-off relation in diversified firm value. From the theoretical results, the trade-off relation come from different aspects. The most three notable theories are: the theory of internal capital market, agency theory, and the theory of debt coinsurance.

First, from the viewpoint of efficient allocation in internal capital market, the internal capital can subsidize the segments that have financial constraint. For example, Stein [2] states that the top managers have insider information about their segments' investment prospects and may thus be able to allocate the internal funds efficiently. In contrast, Rajan, et al. [6] find that a greater diversity of investment opportunities across segments leads to misallocate of internal funds in diversified firms because of the competition among divisions. Finally, Wulf [7] connects the efficiency of allocating internal funds with agency problems and concludes that investment inefficiency depends on three factors: division manager ability to skew information, division manager compensation incentives, and the public image of the investment opportunity. Therefore, the change of firm value in diversification process is inconclusive based on the theory of internal capital market.

Second, from the perspective of agency problem, top managers tend to diversify their company due to three benefit: to increase their control power, compensation and perquisites, to reduce their exposure of firm-specific risk, and to entrench themselves. The empirical finding in [12] supports the notion of private benefits but does not support risk-reducing argument. In addition, Denis, et al. [13] suggests that external corporate control threats, partially alleviate agency problems, limit firms from maintaining a value-reducing diversified status. Hoechle, et al. [14] find evidence that the diversification discount partly result from poor corporate governance. From these findings, the agency theory predicts that there is negative relation between diversification and firm value. The mechanisms that can reduce agency problems would affect the negative relation.

Finally, from the debt coinsurance standpoint, Lewellen [3] argues that the imperfectly correlated cash flows in different segments reduce firm risk and thereby decreases the constraint in debt financing. This is debt co-insurance effect and it can lead to a higher capacity of debt financing and eventually to increase firm value. For example, Dimitrov and Tice [15] find that diversified firms have significantly lower cash flow volatility, which is consistent with [3]. In addition, Kuppuswamy and Villalonga [16] find that firms seek to achieve an equilibrium level of 
external financing and therefore, may not fully utilize their debt capacity. In sum, the trade-off relation between diversification and firm value is still inconclusive and depends on the magnitudes of benefits and cost of diversification. Two extensive literature survey articles are [17. 18].

\subsection{Information Advantage}

The trading activities of insiders and institutional investors reflect private information they own and gradually affect stock prices. The private information may be market-wide, industry-wide, or firm-specific. In addition, different parties may utilize different type of information. The existing literature shows that insiders and institutional investors have substantial influence on stock price. For example, in early stage, Manne [19] states that management can convey their private information to market participants by their trading activity. The improvement of market efficiency is also related to insider trading [20-22]. Based on the definition of insiders, the information released in insider trading is more likely to be firm-specific. Therefore, the advantage or disadvantage of firm diversification, such as agency problems, internal capital market, or debt-coinsurance effect belong to firm-specific information. We expect that insider trading may communicate the related information to the market in the diversification process.

There are different types of institutional investors, such as active or passive, and long-term or short-term investors. The information conveyed in their trading activity depends on the type of institutional investors, their stock ownership, and trading size. For example, Piotroski and Roulstone [8] mention that the greater levels of institutional ownership induce institutional investors to play the monitoring role and increased access to firm-specific information. In addition, large trades are more likely to convey their private information, while small trades are more likely to be portfolio adjustment. Therefore, we utilize the institutional ownership, both level and change of holding, to test the private information regarding the trade-off relation in the diversification process.

Bushee and Goodman [23] find that changes in ownership by institutions with large positions in a firm are consistent with informed trading. In addition, they also find that informed trading is more prevalent in small firms and when the large positions are taken by investment advisers and large institutions. There are different types of institutional investors, such as banks, insurance companies, mutual funds, and investment advisors. Some of them are active but others are passive in monitoring management. Therefore, they have different information advantage or incentive to monitor. For example, Cella [24] shows that firms with long-term institutional investors tend to have lower capital expenditures relative to widely-held firms. Chen, et al. [25] also find that active, rather than passive, institutional investors with long term holdings play the monitoring role in the mergers and acquisition process. Hence, the type of institutional investors and the trade size constitute the informed trading, which is are the key factors in this paper. Other related research includes [26,27]. They also find that institutional investors in general are better informed and that they convey their information through their trades. As to the holding period, Yan and Zhang [28] classify institutional investors into short- and long-term investors based on their past portfolio turnover and show that the positive relationship between institutional ownership and future returns.

\subsection{Research Hypotheses}

The previous literature survey concludes that firm values change after diversification but the overall effect depends on the benefit and cost of diversification. We argue that these benefits, such as efficient allocation in internal capital market and/or debt coinsurance effect and cost, such as agency problems, depend on firm characteristics or situations. These characteristics and situations belong to inside information. It is not possible for outside investors, however, to access the private information but the results of the trade-off relation would eventually reflect into firm's market performance. Therefore, we test the trade-off relation from different aspects: internal capital market and agency problem. Following [1], we examine the relation between the efficiency of internal capital market and firm value by testing the Hypothesis 1 .

Hypothesis 1: The firm value would increase with the efficiency of the internal capital allocation. That is firm values increase when the internal capital allocation is efficient but decrease when it is inefficient.

Utilizing the data of segments' capital expenditure and after-tax cash flows, we can identify subsidy segments, with the amount of the subsidy equal to the capital expenditure excess to their after-tax cash flows. This portion of capital would not be satisfied if the segment were a stand-alone firm.

Jiang and Zaman [29] find that aggregate insider trading is strongly related to unexpected cash-flow news, which is consistent with earlier finding in [22]. Following their findings, we expect partial changes in firm value due to diversification result in the change in future cash flows and insider trading would have predictive ability regarding the change in future cash flows. Based on this rationale, the Hypothesis 2 is as follows.

Hypothesis 2: The insider trading conveys the private information of the change in diversified firm values.

There are two characteristics in institutional ownership that may affect firm value: information advantage and monitoring effect. Therefore, the analysis of change in institutional holdings is more complex than that in insider trading. We analyze the impact of institutional ownership on the trade-off relation from these two aspects. We use the 
type of institutional investors as a proxy for corporate governance mechanism and the level and change of institutional holdings as a proxy for information advantage. Two related hypotheses are as follows.

Hypothesis 3: The change of institutional ownership conveys the private information of the change in diversified firm values.

\section{Data Collection and Research Design}

\subsection{Data Collection}

The key step in this project is to find the sample of diversified firms. We use the COMPUSTAT industry segment database to identify the firms with multiple segments and construct the internal capital market. We require sample firms to have at least two business segments. Following [30-32], the following sample selection criteria is applied:

(1) The firm should have data in both the company and segment COMPUSTAT files;

(2) For any given year, the firm should not have a segment in financial sector (SIC 6000-6999), utilities (SIC 4900-4999), government (SIC 9100-9199), and 'non-classified establishments' (SIC 9900- 9999);

(3) Firm years with sales less than $\$ 20$ million are dropped;

(4) Firm years with missing value of total assets or sales are excluded from the sample.

In addition, we collect daily returns and number of shares outstanding of the sample firms and daily market indices (CRSP VW and EW) from the CRSP database. Annual accounting data of firm-specific variables are collected from the Compustat database. We collect monthly insider trading data from the Thomson CDA Investnet database, and quarterly institutional equity holdings from the Thomson CDA Spectrum database, which are from institutional investors' 13 -f filings. We use the institutional codes in the CDA Spectrum database to identify the type institutional investors. Finally, as to the managerial ownership, we collect the top five managers' stock holding from ExecuComp database for each diversified firm.

\subsection{Variables Description and Empirical Models}

\subsubsection{Internal capital market measure}

We use the segment data of capital expenditure and after-tax cash flows to identify the subsidy to constraint or unconstraint segment and transfer of internal capital. Following [1], we classify segments as providers of internal capital (transfer segments) or receivers of internal capital (subsidy segments) based on the difference between a segment's after-tax cash flow and its capital expenditures.
On the one hand, if a segment's after-tax cash flow is greater than its capital expenditures, then this excess amount is available to subsidize capital expenditure in other segments. On the other hand, if a segment's after-tax cash flow is less than its capital expenditures, then the difference is the subsidy the segment get from other segment. Finally, the resulting net transfer does not exceed the segment's allocated share of subsidies to other segments in a firm. The six types of internal capital allocation are: efficient subsidies to constrained (not constrained) segments, inefficient subsidies to constrained (not constrained) segments, and efficient (inefficient) transfer segments.

\subsubsection{Valuation of firm performance}

We measure the change in firm value after diversification by calculating the buy-and-hold abnormal return of a firm stock as follows:

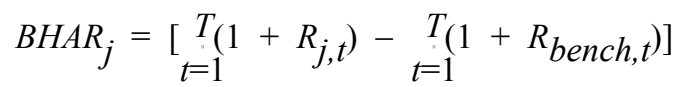

where $R_{j, t}$ and $R_{\text {bench, }}$, respectively, denote firm $j$ 's returns and benchmark returns on day $t$. We calculate return from the fiscal year of firm in the COMPUSTAT industry segment and research files and set a month to have 21 trading days. If the firm is delisted, returns are compounding until the delist date.

\subsubsection{Measure of insider trading}

Following the existing literature, we measure insider-trading behavior using the firm's net insider selling (the number of shares sold minus the number of share purchased) dividend by firm's outstanding shares, defined as

$$
n s h_{t, i}=\frac{\text { Buy }_{t, i}-\text { Sell }_{t, i}}{{\text { Outstanding } \text { shares }_{t, i}}}
$$

where $B u y_{t, i}\left(\operatorname{Sell}_{t, i}\right)$ equals the number of shares purchased (sold) by the registered insiders of firm i during fiscal year $t$. To be consistent with previous research, we restrict transactions to open-market transactions and do not include firm-years where insiders did not purchase or sell their stock.

\subsubsection{Measure of institutional holding}

Like previous studies, we measure institutional shareholdings by number of institutional shares over number of shares outstanding to calculate the percentage of institutional holdings. The second measure is changes in institutional holdings also divided by the number of shares outstanding. Following [33], we set institutional ownership variables to zero if a stock is not held by any institution in CDA Spectrum database.

\subsubsection{Empirical Models}

There are two major issues we focus in the paper. First, we analyze the impact of the allocation of internal capital 
on the firm's long-term performance. To test this issue empirically, we set the empirical model as follows.

$$
\begin{gathered}
\operatorname{BHAR}(0,3)=\beta_{0}+\sum_{\mathrm{i}=1}^{6} \beta_{\mathrm{i}} \mathrm{S}_{\mathrm{i}}+\beta_{7} \mathrm{DR}+ \\
+\beta_{8} \text { SIZE }+\beta_{9} \mathrm{Q}+\beta_{10} \mathrm{PM}+\varepsilon
\end{gathered}
$$

The dependent variable is the three-year BHAR. S1 to S6 represent the different types of internal capital allocation classified by the approach in Billett and Mauer [1]. S1 (S2) denotes efficient subsidies to constrained (not constrained) segments, S3 (S4) denotes inefficient subsidies to constrained (not constrained) segments, and S5 (S6) denotes efficient (inefficient) transfer segments. DR is debt ratio measured as (long-term debt+debt in current liability)/total assets, SIZE measured as the natural logarithm of total assets in 1997 dollars, Q is Tobin's Q, which is market-to-book ratio, and PM is the profit margin.

Second, we analyze the impact of informational advantage on firm's long-term performance. To alleviate the possible problem of endogenity, we utilize the two-stage least square method in testing the second issue. The first stage of the empirical model is as follows.

$$
\begin{gathered}
\text { chgholding, pnsh, or nnsh }=\beta_{0}+\sum_{\mathrm{i}=1}^{6} \beta_{\mathrm{i}} \mathrm{S}_{\mathrm{i}}+ \\
+\beta_{7} \mathrm{DR}+\beta_{8} \mathrm{SIZE}+\beta_{9} \mathrm{Q}+\beta_{10} \mathrm{PM}+\varepsilon
\end{gathered}
$$

The dependent variable is the change of institutional holding, chgholding, positive net sell of insider trading, pnsh, or negative net sell of insider trading, nnsh. The control variables are the same as the Eq. (3). The second stage of the empirical model is as follows. $\begin{aligned} \operatorname{BHAR}(0,3)= & \beta_{0}+\beta_{1} \text { chgholdhat }+\beta_{2} \text { chgholdres } \\ & +\beta_{3} \text { pnshhat }+\beta_{4} \text { pnshres }+\end{aligned}$

$$
\begin{gathered}
\beta_{5} \text { nnshhat }+\beta_{6} \text { nnshres }+\beta_{7} \text { DR }+\beta_{8} \text { SIZE }+\beta_{9} Q+\beta_{10} \\
P M+\varepsilon
\end{gathered}
$$

chgholdhat is the fitted value of the change of institutional holding and chgholdres is the change of institutional holding that is orthogonal to chgholdhat. pnshhat is the fitted positive net sell and pnshres is the positive net sell that is orthogonal to pnshhat. nnshhat is the fitted negative net sell and nnshres is the negative net sell that is orthogonal to nnshhat. The control variables are the same as the Eq. (3).

\section{Empirical results}

\subsection{Summary Statistics}

The empirical tests in this section are based on summary statistics and regression analysis. The result of summary statistics provides preliminary evidence. Therefore, the summary statistics of firm characteristics and segments' characteristics are in Table 1.

The summary statistics in Panel A show that most of diversified firms have positive earnings. The tenth percentile of EBIT is 1.45 million dollars and the first quintile of ROA is $0 \%$. That is these diversified firms have positive accounting performance. Moreover, the ninetieth percentile of debt ratio is $54 \%$ implies that most diversified firms have relatively low debt financing, and further the relative low interest obligations. In sum, the allocation of the internal capital to different segments in these firms becomes important.

Table 1. Summary Statistics

\begin{tabular}{cccccccc}
\hline & \multicolumn{7}{c}{ Panel A. Firm Characteristics } \\
\hline Variable & Mean & Med & STD & P10 & P90 & Q1 & Q3 \\
\hline TA & 9976.68 & 1272.00 & 41748.63 & 79.03 & 17330.0 & 298.51 & 4813.25 \\
\hline EBIT & 1285.71 & 139.40 & 4654.10 & 1.45 & 2599.00 & 21.67 & 600.42 \\
\hline MB & 1.67 & 1.29 & 3.15 & 0.89 & 2.42 & 1.04 & 1.73 \\
\hline LIQ & 0.09 & 0.11 & 0.30 & -0.01 & 0.21 & 0.07 & 0.16 \\
\hline TATO & 0.99 & 0.83 & 0.75 & 0.29 & 1.81 & 0.51 & 1.26 \\
\hline DR & 0.27 & 0.22 & 0.36 & 0.00 & 0.54 & 0.09 & 0.36 \\
\hline ROA & -0.04 & 0.04 & 0.90 & -0.13 & 0.15 & 0.00 & 0.09 \\
\hline Variable & Mean & Med & STD & P10 & P90 & Q1 & Q3 \\
\hline ROA & 0.16 & 0.13 & 0.24 & -0.02 & 0.37 & 0.06 & 0.22 \\
\hline REVTS & 2200.01 & 269.31 & 8656.15 & 9.82 & 5249.00 & 56.57 & 1422.00 \\
\hline TA & 3023.71 & 355.98 & 15632.87 & 15.60 & 6785.77 & 74.06 & 1711.53 \\
\hline ATCF & 321.91 & 27.81 & 1458.87 & -1.54 & 719.27 & 2.54 & 180.70 \\
\hline SUB & 187.71 & 14.47 & 770.76 & 0.53 & 293.10 & 2.48 & 75.98 \\
\hline TRAN & 77.93 & 3.92 & 541.43 & 0.13 & 109.16 & 0.67 & 22.40 \\
\hline
\end{tabular}


The summary statistics in Panel A are firm characteristics and Panel B are segment characteristics. The variables in Panel A are as follows: TA is total asset measured in millions, EBIT is operating income before interest, taxes, and depreciation measured in millions, $\mathrm{MB}$ is market to book ratio measured as (market value of equity/book value of common equity), LIQ is liquidity measured as (cash + marketable securities)/total assets, TATO is total asset turnover measured as sales/total asset, $\mathrm{DR}$ is debt ratio measured as (long-term debt+debt in current liability)/total assets, ROA is return on asset measured as EBIT/TA. The variables in Panel B are as follows: ROA is return on asset measured as earnings before interest, taxes, and depreciation to total assets for each segment, REVTS is total revenues measure in millions, TA is identifiable total assets measured in millions, ATCF is after-taxes cash flows for each segment, SUB is subsidy of internal capital to the segments and TRAN is internal capital transferred from the segments. Both SUB and TRAN are estimated by the method in [1].

The results of segments in Panel B show that most of segments have positive ROA but the revenues vary a lot. The differences of segments' sizes also vary substantially which makes the allocation of internal capital become more complex. Compared with the mean and median of transferring amount, the subsidies are bigger in size and have greater variation. Because the subsidies are estimated by the portion of capital expenditure over the segments' after-tax cash flows, some subsidies need to be supported by external financing. We focus on the efficiency of the allocation of internal capital market in this paper, and leave the external financing to future studies.

\subsection{The Impact of Internal Capital Market}

We estimate the value of internal capital market by the approach in [1] and separate the whole sample into three subgroups by the value. The first hypothesis we would like to test is the impact of internal capital market on firm's long-term performance. The long-term performance is measure by the 1-year, 2-year, and 3-year buy-and-hold abnormal return (BHAR). The summary statistics are in Table 2.

The buy-and-hold abnormal return is estimated in one, two, and three years periods and start from the end of the fiscal year. The benchmark is CRSP value-weighted index. The results based on the equal-weighted index, however, is qualitatively the same.

From Table 2, we find that the two-year and three-year BHARs increase with the value of internal capital market, both in results of mean and median. The 1-year BHAR, however, shows the mixed result, which implies that the impact of internal capital market becomes more significant in the longer period of time. Based on this result, we perform the later regression by using two-year and three-year BHARs as the measure of long-term performance.

Table 2. The long-term performance with respect to internal capital market

\begin{tabular}{lccccc}
\hline Variable & Mean & Med & STD & Q1 & Q3 \\
\hline & & The value of internal capital market-Low & & 0.222 \\
\hline BHAR-1 year & 0.048 & -0.026 & 0.572 & -0.267 & 0.280 \\
\hline BHAR-2 year & 0.063 & 0.012 & 0.585 & -0.318 & 0.305 \\
\hline BHAR-3 year & 0.083 & 0.010 & 0.670 & -0.341 & 0.189 \\
\hline BHAR-1 year & 0.116 & The value of internal capital market-Medium & & 0.205 \\
\hline BHAR-2 year & 0.175 & 0.017 & 0.945 & -0.164 & 0.236 \\
\hline BHAR-3 year & 0.172 & 0.026 & 1.344 & -0.181 & -0.201 \\
\hline BHAR-1 year & 0.027 & 0.026 & 1.160 & & 0.228 \\
\hline BHAR-2 year & 0.207 & The value of internal capital market-High & 0.360 & -0.176 & 0.311 \\
\hline BHAR-3 year & 0.346 & 0.009 & 0.109 & 0.616 & -0.009 \\
\hline
\end{tabular}


The results in Table 2 is univariate analysis and we consider other effect of firm characteristics by performing the regression analysis. The results is summarized in Table 3.

The dependent variable is the three-year BHAR and the number in parentheses is $p$ value. $S 1$ to $S 6$ represent the different types of internal capital allocation classified by the approach in [1]. S1 (S2) denotes efficient subsidies to constrained (not constrained) segments, S3 (S4) denotes inefficient subsidies to constrained (not constrained) segments, and S5 (S6) denotes efficient (inefficient) transfer segments. DR is debt ratio measured as (long-term debt+debt in current liability)/total assets, SIZE measured as the natural logarithm of total assets in 1997 dollars, Q is Tobin's Q, which is market-to-book ratio, and PM is the profit margin. The result is robust with the consideration of collinearity.

The model (1) shows that there is no significant impact of efficient subsidies on the long-term performance. The model (2), however, investors response negatively to inefficient subsidies of constrained segments. Finally, investors react positively to both efficient and inefficient transfer and we suspect that this effect is due to firm's surplus in internal capital market regardless of the efficiency of the allocation. These results still hold in the model (4), which take all types of internal market into account. The results partially support the Hypothesis 1, especially in the inefficient subsidies to constrained segments and efficient transfer segments.

\subsection{The Impact of Internal Capital on the Insider Trading}

Next, we test how the insiders and institutional investors react to the internal capital market. Based on the data of insider trading and the change of institutional holding, we can find the relationship between the informed traders and the inside information of internal capital. First, we check the insider trading around the last month of the fiscal year of diversified firms with respect to the classification of internal capital. Table 4 shows the summary statistics of net sell with and without efficient subsidies to constrained segments.

Table 3. The impact of internal capital allocation on market performance

\begin{tabular}{|c|c|c|c|c|}
\hline Variable & (1) & (2) & (3) & (4) \\
\hline \multirow[t]{2}{*}{$\mathrm{S} 1$} & 46.815 & & & 26.338 \\
\hline & $(0.306)$ & & & $(0.475)$ \\
\hline \multirow[t]{2}{*}{$\mathrm{S} 2$} & 0.014 & & & -0.006 \\
\hline & $(0.682)$ & & & $(0.845)$ \\
\hline \multirow[t]{2}{*}{$\mathrm{S} 3$} & & $\begin{array}{c}-4,705.215 * \\
* *\end{array}$ & & $\begin{array}{c}-5,072.281 * \\
* *\end{array}$ \\
\hline & & $(0.000)$ & & $(0.000)$ \\
\hline \multirow[t]{2}{*}{ S4 } & & 39.427 & & 12.493 \\
\hline & & $(0.878)$ & & $(0.961)$ \\
\hline \multirow[t]{2}{*}{ S5 } & & & $24.021 * *$ & $22.241 * * *$ \\
\hline & & & $(0.013)$ & $(0.007)$ \\
\hline \multirow[t]{2}{*}{ S6 } & & & $6.026 * * *$ & $5.928 * * *$ \\
\hline & & & $(0.000)$ & $(0.000)$ \\
\hline \multirow[t]{2}{*}{ DR } & 0.192 & 0.195 & 0.258 & 0.257 \\
\hline & $(0.459)$ & $(0.452)$ & $(0.338)$ & $(0.341)$ \\
\hline \multirow[t]{2}{*}{ SIZE } & -0.012 & -0.015 & -0.019 & -0.019 \\
\hline & $(0.493)$ & $(0.412)$ & $(0.286)$ & $(0.306)$ \\
\hline \multirow[t]{2}{*}{ Q } & $-0.050 * *$ & $-0.051 * *$ & $-0.043 *$ & $-0.043 *$ \\
\hline & $(0.044)$ & $(0.043)$ & $(0.054)$ & $(0.055)$ \\
\hline \multirow[t]{2}{*}{ PM } & 0.118 & 0.125 & 0.099 & 0.096 \\
\hline & $(0.307)$ & $(0.272)$ & $(0.401)$ & $(0.417)$ \\
\hline \multirow[t]{2}{*}{ Constant } & -0.225 & -0.215 & -0.188 & -0.190 \\
\hline & $(0.222)$ & $(0.244)$ & $(0.292)$ & $(0.290)$ \\
\hline $\begin{array}{l}\text { Adjusted } \\
\text { R-squared }\end{array}$ & 0.167 & 0.165 & 0.175 & 0.171 \\
\hline
\end{tabular}

Table 4. The change of insider trading (SD1)

\begin{tabular}{ccccccccccc}
\hline \multicolumn{1}{c}{ SD1 $=0$} \\
\hline Period & Mean & median & STD & Q1 & Q3 & Mean & median & STD & Q1 & Q3 \\
\hline$(-6,-3)$ & 0.4614 & -0.0001 & 6.0670 & -0.0334 & 0.0246 & -0.0341 & -0.0010 & 0.0820 & -0.0308 & 0.0000 \\
$(-6,-2)$ & 0.5147 & -0.0003 & 6.0460 & -0.0384 & 0.0289 & -0.0341 & -0.0010 & 0.0820 & -0.0308 & 0.0000 \\
$(-6,-1)$ & 1.2026 & -0.0002 & 15.2610 & -0.0498 & 0.0358 & -0.0288 & -0.0001 & 0.0760 & -0.0081 & 0.0000 \\
$(-6,1)$ & 1.1297 & -0.0005 & 14.8930 & -0.0585 & 0.0419 & -0.0307 & -0.0011 & 0.0800 & -0.0107 & 0.0000 \\
$(-6,2)$ & 1.2486 & -0.0004 & 14.9750 & -0.0632 & 0.0628 & -0.0391 & -0.0011 & 0.1160 & -0.0107 & 0.0000 \\
$(-6,3)$ & 1.2337 & -0.0004 & 14.8300 & -0.0632 & 0.0628 & -0.0453 & -0.0018 & 0.1390 & -0.0107 & 0.0000 \\
$(-6,6)$ & 1.0533 & -0.0012 & 14.9420 & -0.0933 & 0.0697 & 0.3805 & -0.0012 & 1.7940 & -0.0107 & 0.0039 \\
$(-6,12)$ & 1.0727 & -0.0012 & 14.6050 & -0.1250 & 0.0686 & 0.4657 & -0.0012 & 2.4090 & -0.0409 & 0.0039 \\
$(-6,24)$ & 2.1213 & -0.0008 & 20.1460 & -0.1816 & 0.1084 & 0.4506 & -0.0024 & 2.7530 & -0.0409 & 0.0039 \\
$(-1,1)$ & 1.0560 & 0.0000 & 17.1840 & -0.0422 & 0.0326 & -0.0025 & -0.0008 & 0.0070 & -0.0027 & 0.0000 \\
\hline
\end{tabular}


The numbers show in the table is the percentage number of net sell of insider trading, which is calculated by the firm's net insider selling (the number of shares sold minus the number of share purchased) dividend by firm's outstanding shares. SD1 is the dummy variable and equal to one when the firm has positive $\mathrm{S} 1$, which is efficient subsidies to constrained segments, and zero elsewhere. The event windows are started from the last month of the fiscal year.

In Table 4, we find that insider net sell is much higher in firms without the efficient subsidies to constrained segments, which implies that insiders react positively to the efficient subsidies to constrained segments. In addition, the variation is also smaller in the firms with efficient subsidies to constrained segments than in other firms.

The numbers show in the table is the percentage number of net sell of insider trading, which is calculated by the firm's net insider selling (the number of shares sold minus the number of share purchased) dividend by firm's outstanding shares. SD2 is the dummy variable and equal to one when the firm has positive S2, which is efficient subsidies to not constrained segments, and zero elsewhere. The event windows are started from the last month of the fiscal year.
From table 5, we find that most of firms with efficient subsidies to not constrained segments have greater net sell than other firms. This implies that the insiders value negatively to the efficient subsidies to not constrained segments. The negative valuation exists no longer than two years after the end of the fiscal year. In addition, the period between one month before and after the end of the fiscal year does not have the negative valuation. Next, we test the insider trading from the viewpoint of the efficiency of transfer and summarize the results in Table 6.

From Table 6, we find that the firms with efficient transfer segments have also negative mean of net sell, which implies the net purchase. The firms without efficient transfer segments, in contrast, have all positive mean of net sell. Therefore, insiders react the efficient transferring positively, which is consistent with our expectation that insider might use the information advantage of transfer segments in the reallocation of their portfolios. The results of median also supports the expectation. Overall, the pattern of insider trading around the end of fiscal year shows that the trading behavior is consistent with the efficiency of the allocation of internal capital. Whether this information advantage helps the predication of firm's long-term performance is the question we will test at the end of this section.

Table 5. The change of insider trading (SD2)

\begin{tabular}{ccccccccccc}
\hline \multicolumn{1}{c}{ SD2 $=0$} \\
\hline Period & Mean & median & STD & Q1 & Q3 & Mean & median & STD & Q1 & Q3 \\
\hline$(-6,-3)$ & 0.4191 & -0.0001 & 6.0470 & -0.0332 & 0.0214 & 1.0952 & -0.0138 & 3.4460 & -0.0888 & 0.0250 \\
$(-6,-2)$ & 0.4421 & -0.0003 & 5.9850 & -0.0339 & 0.0254 & 1.8377 & -0.0024 & 5.0270 & -0.0888 & 0.0250 \\
$(-6,-1)$ & 1.1333 & -0.0002 & 15.2510 & -0.0431 & 0.0346 & 1.8460 & -0.0058 & 5.0260 & -0.1066 & 0.0250 \\
$(-6,1)$ & 1.0659 & -0.0005 & 14.9010 & -0.0581 & 0.0378 & 1.7379 & 0.0003 & 4.9370 & -0.0828 & 0.0557 \\
$(-6,2)$ & 1.1865 & -0.0005 & 14.9830 & -0.0582 & 0.0404 & 1.6349 & -0.0036 & 4.7990 & -0.0768 & 0.0250 \\
$(-6,3)$ & 1.1569 & -0.0006 & 14.8470 & -0.0613 & 0.0473 & 1.9405 & -0.0155 & 6.1420 & -0.0888 & 0.0349 \\
$(-6,6)$ & 1.0109 & -0.0010 & 14.9900 & -0.0899 & 0.0663 & 1.4679 & -0.0155 & 6.1230 & -0.0808 & 0.0421 \\
$(-6,12)$ & 1.0390 & -0.0012 & 14.6830 & -0.1164 & 0.0652 & 1.3499 & 0.0000 & 5.8430 & -0.1124 & 0.1056 \\
$(-6,24)$ & 2.0971 & -0.0009 & 20.2860 & -0.1801 & 0.0859 & 1.5259 & 0.0000 & 5.7740 & -0.0808 & 0.6830 \\
$(-1,1)$ & 1.0480 & 0.0000 & 17.1170 & -0.0417 & 0.0291 & -0.0090 & 0.0000 & 0.0510 & -0.0416 & 0.0006 \\
\hline
\end{tabular}

Table 6. The change of insider trading (SD5)

\begin{tabular}{ccccccccccc}
\hline \multicolumn{1}{c}{ SD5 $=0$} \\
\hline Period & Mean & median & STD & Q1 & Q3 & Mean & median & STD & Q1 & Q3 \\
\hline$(-6,-3)$ & 0.4600 & -0.0001 & 6.0500 & -0.0332 & 0.0225 & -0.0852 & -0.0264 & 0.1830 & -0.1124 & 0.0060 \\
$(-6,-2)$ & 0.5146 & -0.0003 & 6.0380 & -0.0339 & 0.0268 & -0.0807 & -0.0039 & 0.1840 & -0.1124 & 0.0060 \\
$(-6,-1)$ & 1.1977 & -0.0002 & 15.2210 & -0.0474 & 0.0355 & -0.0756 & -0.0021 & 0.1890 & -0.0946 & 0.0144 \\
$(-6,1)$ & 1.1262 & -0.0004 & 14.8570 & -0.0581 & 0.0419 & -0.1048 & -0.0250 & 0.1830 & -0.1729 & 0.0087 \\
$(-6,2)$ & 1.2413 & -0.0004 & 14.9220 & -0.0582 & 0.0499 & -0.1048 & -0.0250 & 0.1830 & -0.1729 & 0.0087 \\
$(-6,3)$ & 1.2273 & -0.0005 & 14.7790 & -0.0614 & 0.0562 & -0.1346 & -0.0250 & 0.2290 & -0.1812 & 0.0087 \\
$(-6,6)$ & 1.0652 & -0.0009 & 14.8950 & -0.0872 & 0.0693 & -0.2363 & -0.0966 & 0.3290 & -0.5270 & -0.0250 \\
$(-6,12)$ & 1.0871 & -0.0009 & 14.5790 & -0.1114 & 0.0678 & -0.1473 & -0.0768 & 0.3730 & -0.2640 & -0.0012 \\
$(-6,24)$ & 2.1310 & -0.0005 & 20.1080 & -0.1566 & 0.1054 & -0.1661 & -0.0768 & 0.5790 & -0.2766 & -0.0024 \\
$(-1,1)$ & 1.0452 & 0.0000 & 17.0850 & -0.0414 & 0.0312 & -0.0614 & 0.0010 & 0.1490 & -0.0416 & 0.0114 \\
\hline
\end{tabular}


The numbers show in the table is the percentage number of net sell of insider trading, which is calculated by the firm's net insider selling (the number of shares sold minus the number of share purchased) dividend by firm's outstanding shares. SD5 is the dummy variable and equal to one when the firm has positive S5, which is efficient transfer segments, and zero elsewhere. The event windows are started from the last month of the fiscal year.

\subsection{The Impact of Internal Capital on the Institutional Holding}

The institutional investors, another party of informed traders, may also utilize the information of efficiency of internal capital in their trading. We summarize the institutional holding in Table 7. From Table 7, we find that the mean and median of institutional holding are greater in firms with efficient subsidies to constrained segments during the period between the previous two quarters and the next year of the end of the fiscal year. As the insiders' result, institutional investors also react positively to the efficient subsidies to constrained segments. When we use the classification of efficient subsidies to not constrained segments, institutional investors have lower holding for the firms with subsidies to not constrained segments. The results is shown in the mean and median of institutional holding ratio in Table 8. This trading pattern is consistent with that of insider trading in Table 5, which implies that institutional investors have the similar viewpoint of internal capital market with the insiders.

Table 7. The summary of institutional holding (SD1)

\begin{tabular}{cccccccccccc}
\hline & \multicolumn{3}{c}{ SD1 $=0$} \\
\hline Period & Mean & median & STD & Q1 & Q3 & Mean & median & STD & Q1 & Q3 \\
\hline-4 & 0.574 & 0.624 & 0.261 & 0.358 & 0.795 & 0.643 & 0.609 & 0.192 & 0.471 & 0.823 \\
-3 & 0.574 & 0.637 & 0.265 & 0.351 & 0.795 & 0.625 & 0.629 & 0.179 & 0.482 & 0.792 \\
-2 & 0.543 & 0.600 & 0.273 & 0.334 & 0.771 & 0.747 & 0.796 & 0.128 & 0.689 & 0.818 \\
-1 & 0.539 & 0.593 & 0.268 & 0.320 & 0.750 & 0.750 & 0.799 & 0.125 & 0.692 & 0.810 \\
1 & 0.541 & 0.599 & 0.275 & 0.300 & 0.768 & 0.729 & 0.801 & 0.132 & 0.622 & 0.853 \\
2 & 0.534 & 0.587 & 0.280 & 0.308 & 0.768 & 0.757 & 0.796 & 0.101 & 0.652 & 0.838 \\
3 & 0.530 & 0.587 & 0.274 & 0.301 & 0.758 & 0.737 & 0.777 & 0.113 & 0.629 & 0.810 \\
4 & 0.536 & 0.581 & 0.267 & 0.307 & 0.761 & 0.748 & 0.820 & 0.139 & 0.604 & 0.844 \\
\hline
\end{tabular}

The numbers show in the table is the percentage of firm's outstanding shares hold by institutional investors, which is measured by the number of institutional shares over the number of shares outstanding. SD1 is the dummy variable and equal to one when the firm has positive S1, which is efficient subsidies to constrained segments, and zero elsewhere. The event windows are started from the last quarter of the fiscal year.

Table 8. The summary of institutional holding (SD2)

\begin{tabular}{cccccccccccc}
\hline & \multicolumn{3}{c}{ SD2 $=0$} \\
\hline Period & Mean & median & STD & Q1 & Q3 & Mean & median & STD & Q1 & Q3 \\
\hline-4 & 0.579 & 0.628 & 0.258 & 0.376 & 0.796 & 0.522 & 0.541 & 0.275 & 0.285 & 0.773 \\
-3 & 0.580 & 0.639 & 0.261 & 0.369 & 0.795 & 0.514 & 0.571 & 0.284 & 0.304 & 0.818 \\
-2 & 0.550 & 0.609 & 0.270 & 0.337 & 0.777 & 0.507 & 0.521 & 0.301 & 0.269 & 0.707 \\
-1 & 0.548 & 0.602 & 0.267 & 0.331 & 0.759 & 0.488 & 0.427 & 0.278 & 0.294 & 0.697 \\
1 & 0.548 & 0.611 & 0.272 & 0.312 & 0.773 & 0.491 & 0.427 & 0.300 & 0.259 & 0.751 \\
2 & 0.545 & 0.598 & 0.278 & 0.323 & 0.778 & 0.429 & 0.308 & 0.288 & 0.221 & 0.697 \\
3 & 0.541 & 0.598 & 0.271 & 0.317 & 0.765 & 0.427 & 0.306 & 0.291 & 0.226 & 0.709 \\
4 & 0.547 & 0.584 & 0.266 & 0.321 & 0.773 & 0.442 & 0.371 & 0.267 & 0.245 & 0.689 \\
\hline
\end{tabular}

The numbers show in the table is the percentage of firm's outstanding shares hold by institutional investors, which is measured by the number of institutional shares over the number of shares outstanding. SD2 is the dummy variable and equal to one when the firm has positive S2, which is efficient subsidies to not constrained segments, and zero elsewhere. The event windows are started from the last quarter of the fiscal year.

When we check the institutional holding with respect to the classification of transferring, the result is inconsistent with that of insiders in this classification. Based on the result, we expect that the situation of firm's transfer segments may not be as important as the subsidy segments. 
Table 9. The summary of institutional holding (SD5)

\begin{tabular}{cccccccccccc}
\hline & \multicolumn{3}{c}{ SD5 $=0$} \\
\hline Period & Mean & median & STD & Q1 & Q3 & Mean & median & STD & Q1 & Q3 \\
\hline-4 & 0.581 & 0.628 & 0.258 & 0.377 & 0.796 & 0.395 & 0.302 & 0.270 & 0.190 & 0.633 \\
-3 & 0.581 & 0.638 & 0.261 & 0.381 & 0.796 & 0.358 & 0.304 & 0.243 & 0.204 & 0.338 \\
-2 & 0.552 & 0.612 & 0.271 & 0.337 & 0.777 & 0.404 & 0.341 & 0.255 & 0.212 & 0.575 \\
-1 & 0.549 & 0.606 & 0.267 & 0.331 & 0.757 & 0.393 & 0.324 & 0.252 & 0.234 & 0.572 \\
1 & 0.549 & 0.615 & 0.273 & 0.314 & 0.771 & 0.396 & 0.296 & 0.268 & 0.244 & 0.630 \\
2 & 0.544 & 0.599 & 0.278 & 0.323 & 0.773 & 0.375 & 0.288 & 0.285 & 0.212 & 0.553 \\
3 & 0.540 & 0.604 & 0.272 & 0.310 & 0.762 & 0.367 & 0.277 & 0.272 & 0.208 & 0.555 \\
4 & 0.546 & 0.589 & 0.265 & 0.321 & 0.763 & 0.380 & 0.280 & 0.289 & 0.211 & 0.584 \\
\hline
\end{tabular}

The numbers show in the table is the percentage of firm's outstanding shares hold by institutional investors, which is measured by the number of institutional shares over the number of shares outstanding. SD5 is the dummy variable and equal to one when the firm has positive S5, which is efficient transfer segments, and zero elsewhere. The event windows are started from the last quarter of the fiscal year.

\subsection{The Long-term Performance}

Finally, we use the two-stage regression to test the impact of the change of institutional holding and insider trading on the firm's long-term performance. To deal with the possibility of endogeneity, we use the two-stage regression. In stage 1 , we check the impact of internal capital market on institutional holding and insider trading. Then, in stage 2, we use the fitted value of institutional holding and insider trading to test their impact on the firm's long-term performance. The results of stage 1 are summarized in Table 10.

From the Model (1) in Table 10, we find that the S3, which is inefficient subsidies to constrained segments, has significantly positive impact on the change of institutional holding. The S6, which is inefficient transfer segments has significantly negative impact on the change of institutional holding. The results imply that institutional investors pay more attention on the inefficiency of transfer segments and the subsidies to constrained segments. In addition, Models (2) and (3) show that S2, which is efficient subsidies to not constrained segments, and S6 have significant impact on the insider trading, especially the negative net sell. That is insiders sell fewer stocks when the efficient subsidies flows to not constrained segments and sell more stock when the transfer is inefficient. Based on the results, we test the impact of both informed traders on the long-term performance in Table 11.

The dependent variable is the change of institutional holding, chgholding, in model (1), positive net sell of insider trading, pnsh, in model (2), and negative net sell of insider trading, nnsh, in model (3). The number in parentheses is $\mathrm{p}$ value. S1 to S6 represent the different types of internal capital allocation classified by the approach in [1]. S1 (S2) denotes efficient subsidies to constrained (not constrained) segments, S3 (S4) denotes inefficient subsidies to constrained (not constrained) segments, and S5 (S6) denotes efficient (inefficient) transfer segments. DR is debt ratio measured as (long-term debt + debt in current liability)/total assets, SIZE measured as the natural logarithm of total assets in 1997 dollars, Q is Tobin's Q, which is market-to-book ratio, and PM is the profit margin. The result is robust with the consideration of collinearity.

Table 10. Regression of long-term performance (Stage 1)

\begin{tabular}{|c|c|c|c|}
\hline Variable & $(1)$ & $(2)$ & (3) \\
\hline & chgholding & pnsh & nnsh \\
\hline \multirow[t]{2}{*}{ S1 } & -2.293 & -0.065 & -0.001 \\
\hline & $(0.259)$ & $(0.558)$ & $(0.966)$ \\
\hline \multirow[t]{2}{*}{ S2 } & -0.000 & 0.000 & $-0.000 * *$ \\
\hline & $(0.655)$ & $(0.203)$ & $(0.029)$ \\
\hline \multirow[t]{2}{*}{ S3 } & $117.425^{* *}$ & -14.289 & 2.667 \\
\hline & $(0.049)$ & $(0.350)$ & $(0.233)$ \\
\hline \multirow[t]{2}{*}{ S4 } & -10.970 & -0.654 & 0.131 \\
\hline & $(0.310)$ & $(0.400)$ & $(0.820)$ \\
\hline \multirow[t]{2}{*}{ S5 } & 0.082 & 0.117 & -0.011 \\
\hline & $(0.777)$ & $(0.162)$ & $(0.153)$ \\
\hline \multirow[t]{2}{*}{ S6 } & $-0.237 * * *$ & -0.009 & $0.017 * * *$ \\
\hline & $(0.000)$ & $(0.247)$ & $(0.000)$ \\
\hline \multirow[t]{2}{*}{ DR } & 0.010 & $0.014 *$ & -0.000 \\
\hline & $(0.250)$ & $(0.066)$ & $(0.503)$ \\
\hline \multirow[t]{2}{*}{ SIZE } & -0.000 & -0.000 & $0.000 * *$ \\
\hline & $(0.979)$ & $(0.587)$ & $(0.026)$ \\
\hline \multirow[t]{2}{*}{ Q } & 0.001 & -0.000 & 0.000 \\
\hline & $(0.610)$ & $(0.423)$ & $(0.189)$ \\
\hline \multirow[t]{2}{*}{$\mathrm{PM}$} & $0.022 * *$ & 0.004 & 0.000 \\
\hline & $(0.012)$ & $(0.163)$ & $(0.875)$ \\
\hline \multirow[t]{2}{*}{ Constant } & -0.002 & -0.001 & $-0.001 * * *$ \\
\hline & $(0.708)$ & $(0.702)$ & $(0.007)$ \\
\hline Adjusted R-squared & -0.028 & 0.075 & 0.077 \\
\hline
\end{tabular}

From Table 11, we find that insiders play more important role in the long-term performance relative to 
institutional investors. The fitted value of positive and negative net sell and the residuals of positive net sell have significant impact on the long-term performance. The change of institutional holding does not have significant effect on the long-term performance. The nnsh, which denotes net purchase, has stronger effect than pnsh and this implies that net purchase signals the better future performance in the diversified firms.

Table 11. Regression of long-term performance (Stage 2)

\begin{tabular}{|c|c|c|}
\hline Variable & (1) & (2) \\
\hline \multirow[t]{2}{*}{ chgholdhat } & -17.245 & \\
\hline & $(0.158)$ & \\
\hline \multirow[t]{2}{*}{ chgholdres } & -0.367 & \\
\hline & $(0.681)$ & \\
\hline \multirow[t]{2}{*}{ pnshhat } & & $242.083 * * *$ \\
\hline & & $(0.005)$ \\
\hline \multirow[t]{2}{*}{ pnshres } & & $3.381 * * *$ \\
\hline & & $(0.002)$ \\
\hline \multirow[t]{2}{*}{ nnshhat } & & $440.661^{* * *}$ \\
\hline & & $(0.000)$ \\
\hline \multirow[t]{2}{*}{ nnshres } & & 10.293 \\
\hline & & $(0.443)$ \\
\hline \multirow[t]{2}{*}{$\mathrm{DR}$} & 0.369 & $-2.949 * * *$ \\
\hline & $(0.199)$ & $(0.007)$ \\
\hline \multirow[t]{2}{*}{ SIZE } & -0.011 & $-0.048 * *$ \\
\hline & $(0.518)$ & $(0.022)$ \\
\hline \multirow[t]{2}{*}{$\mathrm{Q}$} & -0.046 & -0.025 \\
\hline & $(0.132)$ & $(0.447)$ \\
\hline \multirow[t]{2}{*}{$\mathrm{PM}$} & 0.347 & $-1.041 * *$ \\
\hline & $(0.406)$ & $(0.027)$ \\
\hline \multirow[t]{2}{*}{ Constant } & $0.503 * * *$ & $1.336^{* * *}$ \\
\hline & $(0.006)$ & $(0.000)$ \\
\hline Adjusted R-squared & 0.168 & 0.173 \\
\hline
\end{tabular}

The dependent variable in the table is three-year BHAR the number in parentheses is $p$ value. chgholdhat is the fitted value of the change of institutional holding and chgholdres is the change of institutional holding that is orthogonal to chgholdhat. pnshhat is the fitted positive net sell and pnshres is the positive net sell that is orthogonal to pnshhat. nnshhat is the fitted negative net sell and nnshres is the negative net sell that is orthogonal to nnshhat. DR is debt ratio measured as (long-term debt+debt in current liability)/total assets, SIZE measured as the natural logarithm of total assets in 1997 dollars, Q is Tobin's Q, which is market-to-book ratio, and PM is the profit margin. The result is robust with the consideration of collinearity.

\section{Conclusions}

Informed traders have information advantage about the major corporate events and sometimes they utilize the advantage in their trading behavior. The diversified firms may exist the serious problem of information asymmetry. We analyze this topic from the efficiency of internal capital market. There are three major findings in this paper. First, the inefficient subsidies to constrained firms have significantly negative impact on the firm's long-term performance. In addition, the diversified firms with transfer segments, both efficient and inefficient transfer, have significantly positive effect on the firm's performance. Therefore, not every types of internal capital market, defined in [1] have significant influence on firm's market performance.

Second, the insiders and institutional investors of diversified firms may use similar information regarding the internal capital market because they show the similar trading behavior with respect to efficient subsidies to both constrained and not constrained segments. Their reaction to the transfer segments, however, exhibits different patterns. The institutional investors have lower holdings when the diversified firms with efficient transfer segments but the insiders of these firms become net purchase of firms' stocks. Hence, we expect that both types of investors have different opinions with respect to the efficiency of transfer segments.

Finally, the insiders play more important role in the future market performance. Even though some types of internal capital market have significant impact on both the change of institutional holding and insider trading, the long-term market performance is significantly determined by insider trading, especially the negative net sell. In sum, we conclude that both institutional investors and insiders have some information advantage of internal capital market. Insiders, however, have stronger impact on the diversified firms' future performance.

\section{REFERENCES}

[1] M. T. Billett and D. C. Mauer, Cross-subsidies, external financing constraints, and the contribution of the internal capital market to firm value, Review of Financial Studies, Vol. 16, No. 4, pp. 1167-1201, 2003.

[2] J. C. Stein, Internal capital markets and the competition for corporate resources, Journal of Finance, Vol. 52, No. 1, pp. 111-133, 1997.

[3] W. G. Lewellen, A pure financial rationale for the conglomerate merger, The Journal of Finance, Vol. 26, No. 2, pp. 521-537, 1971.

[4] S. Erdorf, T. Hartmann-Wendels, and N. Heinrichs, Diversification in firm valuation: a multivariate copula approach, 2011.

[5] D. S. Scharfstein and J. C. Stein, The dark side of internal capital markets: Divisional rent-seeking and inefficient investment, Journal of Finance, Vol. 55, No. 6, pp. 
$2537-2564,2000$.

[6] R. Rajan, H. Servaes, and L. Zingales, The cost of diversity: The diversification discount and inefficient investment, Journal of Finance, Vol. 55, No. 1, pp. 35-80, 2000.

[7] J. Wulf, Influence and inefficiency in the internal capital market, Journal of Economic Behavior \& Organization, Vol. 72, No. 1, pp. 305-321, 2009.

[8] J. D. Piotroski and D. T. Roulstone, The influence of analysts, institutional investors, and insiders on the incorporation of market, industry, and firm-specific information into stock prices, Accounting Review, Vol. 79, No. 4, pp. 1119-1151, 2004.

[9] B. Baik, J. K. Kang, and J. M. Kim, Local institutional investors, information asymmetries, and equity returns, Journal of Financial Economics, Vol. 97, No. 1, pp. 81-106, 2010.

[10] S. Wahal and J. J. McConnell, Do institutional investors exacerbate managerial myopia?, Journal of corporate Finance, Vol. 6, No. 3, pp. 307-329, 2000.

[11] S. L. Gillan and L. T. Starks, Corporate governance proposals and shareholder activism: the role of institutional investors, Journal of Financial Economics, Vol. 57, No. 2, pp. 275-305, 2000.

[12] R. K. Aggarwal and A. A. Samwick, Why do managers diversify their firms? Agency reconsidered, Journal of Finance, Vol. 58, No. 1, pp. 71-118, 2003.

[13] D. J. Denis, D. K. Denis, and K. Yost, Global diversification, industrial diversification, and firm value, Journal of Finance, Vol. 57, No. 5, pp. 1951-1979, 2002.

[14] D. Hoechle, M. Schmid, I. Walter, and D. Yermack, How much of the diversification discount can be explained by poor corporate governance?, Journal of Financial Economics, Vol. 103, No. 1, pp. 41-60, 2012.

[15] V. Dimitrov and S. Tice, Corporate diversification and credit constraints: Real effects across the business cycle, Review of Financial Studies, Vol. 19, No. 4, pp. 1465-1498, 2006.

[16] V. Kuppuswamy and B. Villalonga, Does Diversification Create Value in the Presence of External Financing Constraints? Evidence from the 2007-2009 Financial Crisis, Management Science, Vol. 62, No. 4, pp. 905-923, 2016.

[17] J. D. Martin and A. Sayrak, Corporate diversification and shareholder value: a survey of recent literature, Journal of Corporate Finance, Vol. 9, No. 1, pp. 37-57, 2003.

[18] S. Erdorf, T. Hartmann-Wendels, N. Heinrichs, and M. Matz, Corporate diversification and firm value: a survey of recent literature, Financial Markets and Portfolio Management, Vol. 27, No. 2, pp. 187-215, 2013.
[19] H. G. Manne, Insider trading and the stock market. Free Press, 1966.

[20] A. Damodaran and C. H. Liu, Insider trading as a signal of private information, Review of Financial Studies, Vol. 6, No. 1, pp. 79-119, 1993.

[21] B. Ke, S. Huddart, and K. Petroni, What insiders know about future earnings and how they use it: Evidence from insider trades, Journal of Accounting \& Economics, Vol. 35, No. 3, pp. 315-346, 2003.

[22] J. D. Piotroski and D. T. Roulstone, Do insider trades reflect both contrarian beliefs and superior knowledge about future cash flow realizations?, Journal of Accounting \& Economics, Vol. 39, No. 1, pp. 55-81, 2005.

[23] B. J. Bushee and T. H. Goodman, Which institutional investors trade based on private information about earnings and returns?, Journal of Accounting Research, Vol. 45, No. 2, pp. 289-321, 2007.

[24] C. Cella, Institutional investors and corporate investment, 2010.

[25] X. Chen, J. Harford, and K. Li, Monitoring: Which institutions matter?, Journal of Financial Economics, Vol. 86, No. 2, pp. 279-305, 2007.

[26] S. Chakravarty, Stealth-trading: Which traders' trades move stock prices?, Journal of Financial Economics, Vol. 61, no. 2, pp. 289-307, 2001.

[27] R. W. Sias, L. T. Starks, and S. Titman, Changes in institutional ownership and stock returns: Assessment and methodology, Journal of Business, Vol. 79, No. 6, pp. 2869-2910, 2006.

[28] X. M. Yan and Z. Zhang, Institutional investors and equity returns: Are short-term institutions better informed?, Review of Financial Studies, Vol. 22, No. 2, pp. 893-924, 2009.

[29] X. Q. Jiang and M. A. Zaman, Aggregate insider trading: Contrarian beliefs or superior information?, Journal of Banking \& Finance, Vol. 34, No. 6, pp. 1225-1236, 2010.

[30] L. H. P. Lang and R. M. Stulz, Tobins-Q, corporate diversification, and firm performance, Journal of Finance, Vol. 49, No. 3, pp. 1079-1080, 1994.

[31] P. G. Berger and E. Ofek, Diversifications effect on firm value, Journal of Financial Economics, Vol. 37, No. 1, pp. 39-65, 1995.

[32] R. Comment and G. A. Jarrell, Corporate focus and stock returns, Journal of Financial Economics, Vol. 37, No. 1, pp. 67-87, 1995.

[33] P. A. Gompers and A. Metrick, Institutional investors and equity prices, Quarterly Journal of Economics, Vol. 116, No. 1, pp. 229-259, 2001. 